\title{
EUROPEAN UNION LAW AND THE CHALLENGES OF CLIMATE CHANGES**
}

\begin{abstract}
The European Union is the party of key international documents dealing with the issue of climate changes: the United Nations Framework Convention on Climate Change, the Kyoto Protocol and the Paris Agreement. Moreover, the European Union has designed a rich legislative framework dedicated to the prevention of climate changes and the suppression of their negative consequences, including numerous decisions, directives, thematic strategies and action programmes. Their main purpose is to minimise and control the emissions of greenhouse gases, in order to contribute to the minimisation of pollution, increase of energy efficiency and the mitigation of negative consequences of climate changes. The reports on the implementation of the aforementioned documents confirm that the application of the measures prescribed by various sources of acquis in this field has given positive results in the European Union countries. However, they also show that climate changes still represent a serious challenge for the legislators as well as for all the other entities whose activities can contribute to this environmental phenomenon. Having in mind the fact that the Republic of Serbia is anticipating the opening of the Negotiation Chapter 27, dedicated to environment and climate changes, the author of this paper analyses relevant international documents of universal character signed by the European Union, sources of the European Union law that are significant for
\end{abstract}

\footnotetext{
*a.batricevic@yahoo.com

** This paper was presented at the International Scientific Conference "Law in the context of addressing the Challenges of the Contemporary World", held at the Faculty of Law, University of Niš, on $13^{\text {th }}-14^{\text {th }}$ April 2018.

The paper represents the result of author's engagement in the Project No. 47011, titled "Crime in Serbia: phenomenology, risks and the possibilities of social intervention" of the Institute of Criminological and Sociological Research, financed by the Ministry of Education, Science and Technological Development of the Republic of Serbia.
} 
facing climate change as well as the reports on achieved results when it comes to combating climate change at the European Union level. The author also discusses international obligations of the Republic of Serbia in this area, its current progress in this field as well as the steps that our country has to take in the future in order to fulfil these obligations.

Key words: European Union, climate changes, environment, ecology, environmental law.

\section{Introduction}

Rapid changes of climate caused by anthropogenic factors started with industrialisation in the middle of the $18^{\text {th }}$ century, leading to the emergence of extreme droughts, floods, storms, heat waves, changes in the water circle regime, increased ice and snow melting on high mountains and poles (Ostojić, 2016: 45). The United Nations Framework Convention on Climate Change, adopted in 1992, defines climate change as "a change of climate which is attributed directly or indirectly to human activity that alters the composition of the global atmosphere and which is in addition to natural climate variability observed over comparable time periods" ${ }^{\prime \prime}$. In its Fifth Report, published in $2013^{2}$, the International Panel for Climate Change (IPCC) confirmed that the climate system is warming as the consequence of anthropogenic emissions of green house gases (Doljak, Petrović, 2015: 15). Fast increase in the concentration of these gases in the atmosphere caused by human activities in the past decades is exactly what led to the imbalance of the atmosphere and its warming on a global scale (Popović, Radulović, Jovanović, 2005).

The negative consequences of climate changes, including the continuous rising of temperature and ozone layer depletion, put at risk the survival of ecosystems, animal and plant species, human lives and health. It is estimated that natural disasters and diseases generated by climate change cause the death of 315,000 people every year (Pajić, 2009). It is also assessed that global economy loses around 125 billion of dollars per year due to climate change, which is more than the amount of financial help that wealthy countries provide to the poor ones (Pajić, 2009). Southern and Central Europe and the Mediterranean are more

1 Article 1, the United Nations Framework Convention on Climate Change, United Nations, 1992, http://unfccc.int/files/essential_background/background_publications_htmlpdf/ application/pdf/conveng.pdf, and Act on the Ratification of United Nations Framework Convention on Climate Change, with Annexes, Official Gazette of the Republic of SerbiaInternational Agreements, No. 2/1997, accessed 10.01.2018.

2 Abbreviated Fifth Report of the International Panel for Climate Change, http://www. hidmet.gov.rs/podaci/ipcc/Skraceni_peti_izvestaj_IPCC.pdf , 10.01.2018. 
frequently facing heat waves, forest fires and droughts, whereas the increase in humidity and floods during the winter period have been noticed in the North. Urban areas, inhabited by four out of five citizens of the European countries, are exposed to heat waves, floods and the rising of the sea level. ${ }^{3}$

Having in mind the devastating consequences of climate change as well as the fact that they are predominantly caused by anthropogenic factors, the European Union is dedicating a significant amount of attention to the establishment and improvement of legislative framework that regulates and controls human activities directly or indirectly contributing to climate change. Moreover, as an international organisation, the European Union has become member of the most important universally applicable international documents dedicated to combating climate change: the United Nations Framework Convention on Climate Change, the Kyoto Protocol and the Paris Agreement, which will be discussed in details further in this paper.

Nowadays, the European Union is considered an international organisation with ambition to become the leader in combating climate changes on the global level. This may have a certain impact on the Republic of Serbia as well, as a country attempting to become its member (Todić, 2014:100-115). Since our country is to open the Negotiation Chapter 27, dedicated to environment protection and climate change ${ }^{4}$, this issue is of special importance, particularly because the Report of the European Commission on the progress of the Republic of Serbia in 2016 emphasises that our country has made certain progress when it comes to further harmonisation of policies and legislation with the acquis in the field of waste, nature protection and climate change, but that the implementation of relevant legal provisions in these areas is still at the early stage. ${ }^{5}$

3 European Commission, Climate Action, Climate Change Consequences, https://ec.europa. eu/clima/change/consequences_en, 10.01.2018.

4 Negotiation team for the negotiations about the accession of the Republic of Serbia to the European Union, Chapter 27: Environment, http://www.eu-pregovori.rs/srl/pregovarackapoglavlja/poglavlje-27-zivotna-sredina/, 10.01.2018.

5 Commission Staff Working Document, Serbia 2016 Report, accompanying the document Communication from the Commission to the European Parliament, the Council, the European Economic and Social Committee and the Committee of the Regions 2016, Communication on EU Enlargement Policy \{COM(2016) 715 final\}, Brussels, 9.11.2016., SWD(2016) 361 final, https://ec.europa.eu/neighbourhood-enlargement/sites/near/files/pdf/key_ documents/2016/20161109_report_serbia.pdf, 26.03.2018. 


\section{International Conventions Relevant to Combating Climate Change ratified by the European Union}

\subsection{The United Nations Framework Convention on Climate Change}

The United Nations Framework Convention on Climate Change was adopted in Rio de Janeiro on 5 May 1992. It came into force on 21 March 1994 and has been ratified by 197 states. $^{6}$ The European Economic Community ratified the Convention on 21 December 1993.

As pointed out in Article 2, the main purpose of the Convention includes the stabilisation of the concentration of greenhouse gases on the level that would prevent negative anthropogenic impacts on the climate system. It is also emphasised that this level should be reached within the time framework that is sufficient to facilitate natural adjustment of ecosystems to climate change, that does not endanger food production and that provides sustainable development. In Article 3 , the duty of the parties to the Convention to protect the climate system for the well-being of present and future generations in accordance with their circumstances and possibilities is highlighted as one of its fundamental principles. In that context, it is underlined that the responsibilities of the parties to the Convention are not the same, as well as that developed countries should take the leading role in combating negative impacts of climate change. On the other hand, the Convention gives full consideration to the needs and circumstances of developing countries, so that they would not have to bear a disproportional or abnormal burden under the Convention.

Article 4 of the Convention prescribes the parties' obligations, such as those regarding the national inventory of anthropogenic emissions by sources and removals by sinks of all greenhouse gases not controlled by the Montreal Protocol, to the extent its capacities permit, obligations regarding national and regional programmes containing measures for climate change mitigation, obligations related to cooperation when it comes to technologies, methods and processes for limitation, minimisation or prevention of anthropogenic emissions of green house gases not controlled by the Montreal Protocol including the energy, transport, industry, agriculture, forestry and waste management sectors.

6 First steps to a safer future: Introducing the United Nations Framework Convention on Climate Change, United Nations Climate Change, http://unfccc.int/essential_background/ convention/items/6036.php, 11.01.2018.

7 Status of Ratification of the United Nations Framework Convention on Climate Change, United Nations Climate Change, http://unfccc.int/essential_background/convention/status_ of_ratification/items/2631.php, 11.01.2018. 
The same Article obliges the parties to the Convention to contribute to a rational use of sinks and reservoirs of all greenhouse gases not controlled by the Montreal Protocol, including biomass, forests and oceans as well as other terrestrial, coastal and marine ecosystems. The parties are also required: to take into consideration climate change, whenever it is possible, when implementing their relevant social, economic and environmental policies and actions; to support each other and cooperate in scientific, technological, technical, socio-economic research, systematic observations and the establishment of a database on climate system; to cooperate in the area of information exchange, education and training regarding the climate change issues, etc. Industrialised countries, listed in Annex I to the Convention, are expected to contribute most when it comes to minimizing emissions. These countries, also known as "Annex I countries" have, among others, the obligation to submit regular reports on their policies and measures in the area of climate change, as well as to submit their national inventories on greenhouse gases emissions.

The European community is also placed in Annex I to the Convention, which means that it is also subject to the aforementioned obligations. Furthermore, the majority of the European Union member states (apart from Malta, Cyprus, Croatia, and Slovenia) belong to the Annex I countries and are also obliged to abide by these obligations.

\subsection{The Kyoto Protocol}

The Kyoto Protocol ${ }^{8}$ was adopted on 11 December 1997, and came into force on 16 February 2005. It obliges industrialised countries, listed in Annex I of the United Nations Framework Convention on Climate Change, to stabilise the emissions of greenhouse gases in accordance with the principles of the Convention. The Protocol sets even stricter obligations and responsibilities regarding the minimisation of the greenhouse gases emissions ${ }^{9}$ In order to encourage sustainable development, Article 2 of the Kyoto Protocol obliges each party included in Annex I to implement and further develop the policies aimed to increase energy efficiency, enhance sustainable agriculture, facilitate research and development of innovative and renewable forms of energy and modern technologies that do not harm the environment, gradually minimise or eliminate market and economic factors responsible for greenhouse gases emissions, enhance reforms in

8 The Kyoto Protocol to the United Nations Framework Convention on Climate Change http:// unfccc.int/resource/docs/convkp/kpeng.pdf, and Act on Ratification of Kyoto Protocol to the United Nations Framework Convention on Climate Change, Official Gazette of the Republic of Serbia-International Agreements, No. br. 88/2007 and 38/2009; accessed 11.01.2018

9 The Kyoto Protocol, United Nations Climate Change, http://unfccc.int/kyoto_protocol/ items/2830.php, 11.01.2018. 
relevant sectors, limit or diminish the emissions of methane (via recycling, for example), promote cooperation, etc.

According to the Kyoto Protocol, 37 industrialized countries and the European Community committed to reduce GHG emissions to an average of 5\% against 1990 levels during the first commitment period, i.e. between 2008 and 2012 . The second commitment period was initiated on 8 December 2012, when the Doha Amendment ${ }^{10}$ was signed. In accordance with this Amendment, which has not yet entered into force, the parties committed to reduce GHG emissions by at least $18 \%$ below 1990 levels in the eight-year period from 2013 to 2020. The European Union ratified the Doha Amendment on 12 June $2015 .{ }^{11}$

\subsection{The Paris Agreement}

The Paris Agreement ${ }^{12}$ was adopted on 12 December 2015 and entered into force on 4 November $2016^{13}$. The European Union ratified the Paris Agreement on 5 October 2016. As highlighted in Article 2, in enhancing the implementation of the Convention, including its objective, the Agreement aims to strengthen the global response to the threat of climate change, in the context of sustainable development and efforts to eradicate poverty. This aim is accomplished by: 1) limiting the increase in the global average temperature to the level "significantly below $2^{\circ}$ Celsius", i.e. continuing the efforts to limit the temperature increase to $1.5^{\circ}$ Celsius as compared to the pre-industrial level; 2) strengthening the capacities to adapt to the negative impacts of climate change, strengthening climate resilience and development based upon low emission of greenhouse gases in a manner that does not endanger food production; and 3) providing appropriate financial resources in accordance with low greenhouse gas emission models and climate adaptable development (Todić, 2016: 53).

10 The Doha Amendment to the Kyoto Protocol, http://unfccc.int/files/kyoto_protocol/ application/pdf/kp_doha_amendment_english.pdf, 26.03.2018.

11 Council Decision on the conclusion, on behalf of the European Union, of the Doha Amendment to the Kyoto Protocol to the United Nations Framework Convention on Climate Change and the joint fulfilment of commitments thereunder, Brussels, 12 June 2015, Interinstitutional File: 2013/0376 (NLE), 10400/5/14 REV 5, http://data.consilium.europa. eu/doc/document/ST-10400-2014-REV-5/en/pdf, 11.01.2018.

12 The Paris Agreement, United Nations, 2015, http://unfccc.int/files/essential_background/ convention/application/pdf/english_paris_agreement.pdf,. and Act on Ratification of the Paris Agreement, Official Gazette of the Republic of Serbia-International Agreements, No. 4/2017; accessed 11.01.2018

13 Reference: C.N.735.2016.TREATIES-XXVII.7.d (Depositary Notification), Paris Agreement, Paris, 12 Dec. 2015, Entry into Force, https://treaties.un.org/doc/Publication/CN/2016/ CN.735.2016-Eng.pdf, 11.01.2018. 
Article 4 of the Paris Agreement confirms that developed countries should maintain the leading role in minimizing greenhouse gas emissions at the total economy level. However, it also calls upon the developing countries to maximise their efforts in the field of climate change mitigation in accordance with their national circumstances and with the support they are provided. Paragraph 6 recognises the importance of facilitating an integrated, comprehensive and balanced access (which is not market-oriented) as assistance to providing nationally determined contribution of individual states. The aim of this is to: promote the measures of mitigation and adjustment, to strengthen the participation of public and private sector in the fulfilment of national contributions, as well as to facilitate the coordination of instruments and relevant institutional arrangements. Under Article 7, the adjustment to climate change is recognised as a global challenge the response to which should include the strengthening of adaptive capacities in order to protect humans, living resources and ecosystems. In that sense, Article 9 prescribes that developed countries should provide financial resources to help developing countries to apply measures for mitigation and adjustment within their current obligations under the Convention.

Article 8 states that Parties recognize the importance of averting, minimizing and addressing loss and damage associated with the adverse effects of climate change, including extreme weather events and slow onset events, and the role of sustainable development in reducing the risk of loss and damage. Therefore, the parties are encouraged to improve understanding, acting and support, inter alia, through the Warsaw International Mechanism for Loss and Damage associated with Climate Change Impacts. Having in mind the importance of technology for the implementation of mitigation and adjustment activities, Article 10 of the Agreement encourages the Parties to persist in their efforts to accelerate, enhance and facilitate innovations for providing an efficient, long-term global response to climate change and promoting economic growth and sustainable development. Article 12 of the Agreement supports the cooperation between the Parties when it comes to the application of measures in order to improve education, raising awareness and informing the public in the field of climate change. Finally, the Agreement (Articles 14-19) provides bodies and mechanisms that enable and facilitate its implementation. 


\section{Sources of the European Union Law relevant to Combating Climate Change}

\subsection{The Seventh EU Environment Action Programme}

The Seventh Environment Action Programme ${ }^{14}$ is the most important strategic document in the area of environment protection policy at the EU level and, as such, is relevant to the climate change issues. It introduces the following key goals: 1) to protect, preserve and improve the natural capital of the Union, 2) to develop the economy within the European Union, which is based upon an efficient use of resources, minimisation of carbon-dioxide emissions and green economy and 3) to protect the citizens of the European Union from the pressures of environment pollution and risks for health and wellbeing.

These goals can be achieved through: 1) better implementation of legislation; 2) better dissemination of information via advanced database; 3) more intensive and rational investing in the development of environment protection and climate change policies; and 4) total integration of requirements and questions related to environment protection into other policies. The Programme proclaims two additional horizontal priority goals: 1) to make the cities in the European Union more sustainable; and 2) to help the European Union face international challenges in the area of environment protection and climate change in a more effective manner. The Programme entered into force at the beginning of 2014, and relevant institutions of the European Union as well as its member states are determined to fulfil its priority goals by $2020 .{ }^{15}$

\subsection{Thematic Strategies relevant to Combating Climate Change}

There are three European Union thematic strategies relevant to the prevention and control of the activities that contribute to the emergence of climate change: 1) the strategy on air pollution, 2) the strategy on soil pollution, and 3) the strategy on the prevention and recycling of waste. These strategies prescribe basic guidelines for the activities aimed at minimizing pollution caused by the emission of various harmful substances, including the ones that are responsible for the emergence of greenhouse gases' effects.

14 Decision No 1386/2013/EU of the European Parliament and of the Council of 20 November 2013 on a General Union Environment Action Programme to 2020 "Living well, within the limits of our planet", Official Journal of the European Union L 354/171, 28.12.2013., http://eurlex.europa.eu/legal-content/EN/TXT/PDF/?uri=CELEX:32013D1386\&from=EN, 11.01.2018.

15 Environment Action Programme to 2020, http://ec.europa.eu/environment/actionprogramme/, 11.01.2018. 
The European Union Thematic Strategy on Air Pollution ${ }^{16}$ was adopted as an addition to current legislation with the purpose to facilitate the reaching of the air quality level that does not allow the increase of negative impact on and risks for human health and environment. The Strategy sets goals in the area of air pollution and suggests measures necessary for their fulfilment by 2020. It focuses on the most harmful pollutants and sets long-term goals regarding their minimisation. The Strategy insists on the simplification of the EU legislation in the area of air quality as well as on the revision of the legislation regulating national emissions ceilings. Besides, it aims to achieve the integration of the air quality issues into other related sectors such as agriculture, energy and traffic.

The European Union Thematic Strategy on Soil Protection ${ }^{17}$ sets frameworks for the activities aimed at achieving a high level of soil protection and introduces measures that should be taken with that purpose. For example, the Strategy considers sustainable use of soil and preventive measures, whereas its measures for discovering problems include: identifying the areas under the risk of erosion, decrease of organic substances, salinisation, landslide, etc. Finally, operational measures entail adopting (by the member states) appropriate programmes for areas under risk, salinisation restriction measures and strategies for the remediation of contaminated areas. The main goal of the Strategy is to prevent further soil degradation and preserve its functions as well as to return the degraded soils to the level of functionality that is compatible with their use. The Strategy is expected to contribute to the integration of the soil protection issue into other sectoral policies such as: spatial planning, traffic, energy, agriculture, rural development, forestry, tourism, trade, industry and climate change.

The EU Thematic Strategy of the European Union on the prevention and recycling of waste $^{18}$ aims to promote recycling, prevention of waste and its disposal on

16 Communication from the Commission to the Council and the European Parliament, Thematic Strategy on air pollution $\{$ SEC(2005) 1132\} \{SEC(2005) 1133\}, Brussels, 21.9.2005. $\operatorname{COM(2005)} 446$ final, http://eur-lex.europa.eu/legal-content/EN/TXT/PDF/?uri=CELEX:5 2005DC0446\&from=EN, 11.01.2017.

17 Communication from the Commission to the Council, the European Parliament, the European Economic and Social Committee and the Committee of the Regions - Thematic Strategy for Soil Protection [SEC(2006)620] [SEC(2006)1165], Brussels, Brussels, 22.9.2006. $\operatorname{COM}(2006) 231$ final , http://eur-lex.europa.eu/legal-content/EN/TXT/PDF/?uri=CELEX:5 2006DC0231\&from=EN, 11.01.2017.

18 Communication from the Commission to the Council, the European Parliament, the European Economic and Social Committee and The Committee of the Regions-Taking sustainable use of resources forward - A Thematic Strategy on the prevention and recycling of waste $\{$ SEC(2005) 1681\} \{SEC(2005) 1682\}, Brussels, 21.12.2005. COM(2005) 666 final, http://eur-lex.europa.eu/legal-content/EN/TXT/PDF/?uri=CELEX:52005DC0666\&from= EN, 11.01.2017. 
landfills as well as the use of waste as a resource. The most important measures for achieving the Strategy goals are as follows: full implementation, simplification and modernisation of current legislation; introduction of the life cycle principle to the waste management policy; promotion of more ambitious policies of waste prevention; advancement of knowledge and information; the development of common minimal recycling standards in all member states, and further improvement of the European Union recycling policy.

\subsection{The Climate and Energy Package 2020}

\subsubsection{Introductory Remarks}

The Climate and Energy Package 2020 is a collection of the sources of the European Union legislation that are relevant to achieving its goals in the area of climate and energy by the year 2020 . This collection of legal provisions sets three core targets of the European Union in this area: 1) 20\% cut in greenhouse gas emissions (in comparison to 1990 levels); 2) 20\% of EU energy from renewable sources and 3) 20\% improvement in energy efficiency. These ambitious targets were set in 2007 and officially incorporated into the European Union legislation in 2009. They also represent the key objectives of the European Union Strategy for Smart, Sustainable and Inclusive Growth ${ }^{19}$ adopted in 2010. They are fulfilled through: emissions trading system, national goals regarding the minimisation emissions, national goals in the area of renewable sources of energy, investing in increasing energy efficiency and financing the development of the technologies that contribute to the minimisation of carbon-dioxide emissions. ${ }^{20}$

\subsubsection{The European Union Emissions Trading System}

The EU Emissions Trading System is the main mechanism for combating climate change and its key method for reducing the greenhouse gas emissions from heavy energy-using installations (such as power stations and industrial plants) and airlines. This system is applied in 31 countries (all $28 \mathrm{EU}$ member states, plus Iceland, Lichtenstein and Norway), facilitating the limitation of emissions from more than 11,000 large industrial installations and covering around 45\% of greenhouse gas emissions in the European Union ${ }^{21}$.

19 Communication from the Commission, Europe 2020 A strategy for smart, sustainable and inclusive growth, Brussels, 3.3.2010. COM(2010) 2020, http://ec.europa.eu/eu2020/ pdf/COMPLET\%20EN\%20BARROSO\%20\%20\%20007\%20-\%20Europe\%202020\%20-\%20 EN\%20version.pdf, 12.01.2018.

20 Climate Action, 2020 climate and energy package, https://ec.europa.eu/clima/policies/ strategies/2020_en, 12.01.2018.

21 The EU Emissions Trading System (EU ETS) Factsheet, https://ec.europa.eu/clima/sites/ clima/files/factsheet_ets_en.pdf, 12.01.2018. 
This system functions in accordance with the "cap and trade" principle. The "cap" represents the entire quantity of greenhouse gases that can be emitted by installations covered by the system. Within the value of the "cap", companies are given emission allowances, which they can trade with one another if necessary. The companies can also buy limited amounts of international credits from emission-saving projects all over the world. The limit on the total number of allowances that are available to the companies ensures that they have a value; the reduction of the value of the "cap" contributes to the reduction of emissions. At the end of the year, each company has to deliver a sufficient amount of allowances to cover all its emissions. If a company fails to do so, it is punished by a fine. ${ }^{22} \mathrm{On}$ the other hand, if a company manages to reduce its emissions, it can either keep the extra allowances to cover its future needs or sell them to another company. ${ }^{23}$

The Directive 2003/87/EC establishing a scheme for greenhouse gas emission allowance trading within the Community was adopted in $2003^{24}$. The functioning of the emission trading system has had several phases. The first phase, named "the pilot period" lasted from 2005 until 2007. The second phase, also known as "the Kyoto period", lasted from 2008 until 2012. The third phase, envisaged for the period from 2013 to 2020, significantly differs from the first two phases. Instead of national caps, a single European Union cap on emissions is applied; free allocation of caps is replaced by auctioning as the default method, and more sectors and gases are included. ${ }^{25}$ Since the founding of this system, several Directives have been adopted for the purpose of facilitating its alterations and improvements. ${ }^{26}$ Thanks to the establishment of this system, the issue of climate

22 Srbija i klimatske promene, EU sistem trgovine emisijama (Serbia and Climate Changes, EU ETS), http://www.klimatskepromene.rs/obaveze-prema-eu/eu-sistem-trgovine-emisijama/, 12.01.2018.

23 EU Emissions Trading System (EU ETS), European Commission, https://ec.europa.eu/ clima/policies/ets_en, 27.03.2018.

24 Directive 2003/87/EC of the European Parliament and of the Council of 13 October 2003 establishing a scheme for greenhouse gas emission allowance trading within the Community and amending Council Directive 96/61/EC, Official Journal of the European Union, L 275/32, 25.10.2003., http://eur-lex.europa.eu/legal-content/EN/TXT/PDF/?uri=CELEX:32003L008 7\&from=EN, 12.01.2018.

25 Climate Action, The EU Emissions Trading System, https://ec.europa.eu/clima/policies/ ets_en\#Main_legislation, 12.01.2018.

26 Directive 2004/101/EC of the European Parliament and of the Council amending Directive 2003/87/EC establishing a scheme for greenhouse gas emission allowance trading within the Community, in respect of the Kyoto Protocol's project mechanisms, Official Journal of the European Union, L 338/18, 13.11.2004., http://eur-lex.europa.eu/legal-content/EN/TXT/PD F/?uri=CELEX:32004L0101\&from=EN; Directive 2008/101/EC of the European Parliament and of the Council amending Directive 2003/87/EC so as to include aviation activities in the 
change is being included in financial plans of many companies and contributed to the promotion of investing in cleaner technologies with low carbon-dioxide emissions. ${ }^{27}$

\subsubsection{National Emission Reduction Targets}

National emission reduction targets cover the sectors that are not included in the emissions trading system and comprise around 55\% of the total greenhouse gas emissions in the European Union coming from the sources such as households, agriculture and waste. On the basis of the Effort Sharing Decision ${ }^{28}$ adopted in 2009, the European Union member states have agreed to respect annual greenhouse gas emissions targets until 2020. National targets depend on national wealth and vary from a $20 \%$ cut for the richest countries to a maximum $20 \%$ increase for the least wealthy ones that are still expected to make efforts to limit their emissions. The Commission supervises the progress of national targets' achievement and each country is obliged to submit annual reports about this issue. ${ }^{29}$ The following Directives are also important for the reduction of national greenhouse gases' emission: 1) Directive 2001/81/EC of the European Parliament and of the Council of 23 October 2001 on national emission ceilings for certain atmospheric pollutants ${ }^{30}$, and 2) Directive 2010/75/EU of the European

scheme for greenhouse gas emission allowance trading within the Community, Official Journal of the European Union, L 8/3, 13.1.2009., http://eur-lex.europa.eu/legal-content/EN/TXT/ PDF/?uri=CELEX:32008L0101\&from=EN; Directive 2009/29/EC of the European Parliament and of the Council of 23 April 2009 amending Directive 2003/87/EC so as to improve and extend the greenhouse gas emission allowance trading scheme of the Community, Official Journal of the European Union, L 140/63, 5.6.2009., http://eur-lex.europa.eu/legal-content/ EN/TXT/PDF/?uri=CELEX:32009L0029\&from=EN;

Directive 2003/87/EC of the European Parliament and of the Council of 13 October 2003 establishing a scheme for greenhouse gas emission allowance trading within the Community and amending Council Directive 96/61/EC, Official Journal of the European Union, 275, 25.10.2003., http://eur-lex.europa.eu/legal-content/EN/TXT/PDF/?uri=CELEX:02003L008720140430\&from=EN, accessed 12.01.2018.

27 Srbija i klimatske promene, EU sistem trgovine emisijama (Serbia and Climate Changes, EU ETS), http://www.klimatskepromene.rs/obaveze-prema-eu/eu-sistem-trgovine-emisijama/, 12.01.2018.

28 Decision No 406/2009/EC of the European Parliament and of the Council of 23 April 2009 on the effort of Member States to reduce their greenhouse gas emissions to meet the Community's greenhouse gas emission reduction commitments up to 2020, Official Journal of the European Union, L 140/136, 5.6.2009., http://eur-lex.europa.eu/legal-content/EN/ TXT/PDF/?uri=CELEX:32009D0406\&from=EN, 12.01.2018.

29 Climate Action, 2020 climate and energy package, https://ec.europa.eu/clima/policies/ strategies/2020_en, 12.01.2018.

30 Directive 2001/81/EC of the European Parliament and of the Council of 23 October 2001 on national emission ceilings for certain atmospheric pollutants, Official Journal of 
Parliament and of the Council of 24 November 2010 on industrial emissions (integrated pollution prevention and control) ${ }^{31}$.

\subsubsection{National Renewable Energy Sources Targets}

Mandatory national targets for the European Union member states regarding the increase in the total share of renewable energy sources in total energy use until 2020 are set by Directive 2009/28/EC of the European Parliament and of the Council of 23 April 2009 on the promotion of the use of energy from renewable sources and amending and subsequently repealing Directives 2001/77/EC and $2003 / 30 / E^{32}$. These targets vary from one country to another, depending on their initial positions in the field of renewable energy sources production and their capacities to expand them further. For example, the increase prescribed for Sweden is $49 \%$, whereas it is only $10 \%$ for Malta. ${ }^{33}$

\subsubsection{Energy Efficiency}

A set of binding measures designed to facilitate the European Union to reach its goals in the field of energy efficiency increase until 2020 is prescribed by Directive 2012/27/EU of the European Parliament and of the Council of 25 October 2012 on energy efficiency ${ }^{34}$. In accordance with this document, all European Union member states are obliged to use the sources of energy in a more efficient manner in all phases, starting from its production until its final use. In order to achieve the $20 \%$ increase in energy efficiency, member states have had to set their national targets which, depending on each country's preferences, can be

the European Communities, L 309/22, 27.11.2001, http://eur-lex.europa.eu/legal-content/ EN/TXT/PDF/?uri=CELEX:32001L0081\&from=EN, 12.01.2018.

31 Directive 2010/75/EU of the European Parliament and of the Council of 24 November 2010 on industrial emissions (integrated pollution prevention and control), Official Journal of the European Union, L 334/17, 17.12.2010., http://eur-lex.europa.eu/legal-content/EN/ TXT/PDF/?uri=CELEX:32010L0075\&from=EN, 12.01.2018.

32 Directive 2009/28/EC of the European Parliament and of the Council of 23 April 2009 on the promotion of the use of energy from renewable sources and amending and subsequently repealing Directives 2001/77/EC and 2003/30/EC, Official Journal of the European Union, L 140/16, 5.6.2009., http://eur-lex.europa.eu/legal-content/EN/TXT/PDF/?uri=CELEX:32 009L0028\&from $=$ EN, 12.01.2018.

33 Climate Action, 2020 climate and energy package, https://ec.europa.eu/clima/policies/ strategies/2020_en, 12.01.2018.

34 Directive 2012/27/EU of the European Parliament and of the Council of 25 October 2012 on energy efficiency, amending Directives 2009/125/EC and 2010/30/EU and repealing Directives 2004/8/EC and 2006/32/EC, Official Journal of the European Union, L 315/1, 14.11.2012., http://eur-lex.europa.eu/legal-content/EN/TXT/PDF/?uri=CELEX:32012L00 27\&from=EN, 12.01.2018. 
based on primary or final energy use, primary or final energy saving or energy intensity. At the end of 2016, the Commission suggested alterations of the Energy Efficiency Directive, including the introduction of a new target - a 30\% increase in the use of renewable energy sources. ${ }^{35}$

\subsection{Climate and Energy Package 2030}

The climate-energy package that refers to the period until 2030 was adopted in $2014^{36}$ and sets the following goals for the European Union: 1) at least $40 \%$ reduction in greenhouse gas emissions (as compared to 1990 levels); 2) at least $27 \%$ share for renewable energy sources; and 3) at least $27 \%$ improvement in energy efficiency. A shared approach in the period until 2030 is expected to provide safety to the investors and coordinated efforts of the EU member states in this field. Such an approach should contribute to the progress in the area of low-carbon economy. It should develop an energy system that ensures affordable energy for all consumers, increases the security of the European Union's energy supplies, reduces the dependence on energy imports, creates new jobs, and brings environmental and health benefits. ${ }^{37}$

\section{Conclusion}

The European Union is on its way to achieve the goals regarding greenhouse gases reduction, increase the share of renewable energy sources and enhance energy efficiency until 2020. The latest reports confirm that the EU greenhouse gas emissions were reduced in the period from 1990 to 2016, when it was estimated to be $23 \%$ below the 1990 level, whereas the economic growth in the same period was $53 \%$. It was also estimated that the total EU emissions fell by $0.7 \%$ from 2015 to 2016, while the overall GDP increased by $1.9 \%{ }^{38}$.

35 The European Commission, Energy, Energy Efficiency, https://ec.europa.eu/energy/en/ topics/energy-efficiency/energy-efficiency-directive, 12.01.2018.

36 Communication from the Commission to the European Parliament, the Council, the European Economic and Social Committee and the Committee of the Regions a policy framework for climate and energy in the period from 2020 to 2030, Brussels, 22.1.2014 $\operatorname{COM}(2014) 15$ final, $\{\operatorname{SWD}(2014) 15$ final $\}\{\operatorname{SWD}(2014) 16$ final $\}$, http://eur-lex.europa.eu/ legal-content/EN/TXT/PDF/?uri=CELEX:52014DC0015\&from=EN, 12.01.2018.

37 Climate Action: 2030 climate and energy framework, https://ec.europa.eu/clima/ policies/strategies/2030_en, 12.01.2018.

38 Report from the Commission to the European Parliament and the Council "Two years after Paris - Progress towards meeting the EU's climate commitments" COM(2017) 646 final \{SWD(2017) 357 final\}, Brussels, 07.11.2017., https://ec.europa.eu/clima/sites/clima/files/ strategies/progress/docs/swd_2017_xxx_en.pdf, 12.01.2018., str. 37. 
The targets of the European Union regarding combating climate change and the measures that the EU member states are required to apply in order to achieve these targets are important for the Republic of Serbia as well, particularly considering the anticipated opening of the Negotiation Chapter 27, dedicated to environment and climate change. According to the United Nations Framework Convention on Climate Change, Serbia is a non-Annex I country, which means that it is not considered a highly-industrialised country whose activities might have a significant impact on climate change. Therefore, the Republic of Serbia does not have the same obligations as some of the most developed EU member states. However, our country is still required to harmonise its national legislation with the provisions of the acquis relevant to this issue.

In that context, it should be noted that, in its Report on the progress of the Republic of Serbia in 2016, the European Commission described the progress of our country in the area of climate change as rather modest and emphasized that additional efforts should be made in that field. The Republic of Serbia is expected to adopt the Act on Climate Change and a series of administrative acts that are necessary for its practical implementation, as well as to integrate the laws, strategies and targets relevant to climate change into other sectors such as energy, traffic, agriculture and waste management.

\section{References}

Council Decision on the conclusion, on behalf of the European Union, of the Doha Amendment to the Kyoto Protocol to the United Nations Framework Convention on Climate Change and the joint fulfilment of commitments thereunder, Brussels, 12 June 2015, Interinstitutional File: 2013/0376 (NLE), 10400/5/14 REV 5, http://data.consilium.europa.eu/doc/document/ST-10400-2014-REV-5/ en/pdf, 11.01.2018.

Doljak, D., Petrović, Lj. (2015) Uzroci i posledice klimatskih promena. U: Luković, J., Đorđević, A. (ur.) Zbornik radova mladih istraživača, Planska i normativna zaštita prostora i životne sredine. Beograd: Asocijacija prostornih planera Srbije i Geografski fakultet Univerziteta u Beogradu, str.13-21.

The European Commission, Energy, Energy Efficiency, https://ec.europa.eu/ energy/en/topics/energy-efficiency/energy-efficiency-directive, 12.01.2018.

Decision No 406/2009/EC of the European Parliament and of the Council of 23 April 2009 on the effort of Member States to reduce their greenhouse gas emissions to meet the Community's greenhouse gas emission reduction commitments up to 2020, Official Journal of the European Union, L 140/136, 5.6.2009, http:// 
eur-lex.europa.eu/legal-content/EN/TXT/PDF/?uri=CELEX:32009D0406\&fro $\mathrm{m}=\mathrm{EN}, 12.01 .2018$.

Directive 2012/27/EU of the European Parliament and of the Council of 25 October 2012 on energy efficiency, amending Directives 2009/125/EC and 2010/30/ EU and repealing Directives 2004/8/EC and 2006/32/EC, Official Journal of the European Union, L 315/1, 14.11.2012, http://eur-lex.europa.eu/legal-content/ EN/TXT/PDF/?uri=CELEX:32012L0027\&from=EN, 12.01.2018.

The European Commission, Climate Action, Climate Change Consequences, https://ec.europa.eu/clima/change/consequences_en, 10.01.2018.

First steps to a safer future: Introducing the United Nations Framework Convention on Climate Change, United Nations Climate Change, http://unfccc.int/ essential_background/convention/items/6036.php, 11.01.2018.

The Kyoto Protocol to the United Nations Framework Convention on Climate Change http://unfccc.int/resource/docs/convkp/kpeng.pdf, 11.01.2018.

Ostojić, G. (2016) Klimatske promene i nacionalna bezbednost, Vojno delo, 68(7), str. 45-67.

Report from the Commission to the European Parliament and the Council "Two years after Paris - Progress towards meeting the EU's climate commitments" COM(2017) 646 final \{SWD(2017) 357 final\}, Brussels, 07.11.2017, retrieved on 12.01. 2018 from: https://ec.europa.eu/clima/sites/clima/files/strategies/ progress/docs/swd_2017_xxx_en.pdf

Pajić, S. (2009) Uticaj klimatskih promena na životnu sredinu, I Naučna konferencija sa međunarodnim učešćem "Ekološka bezbjednost u postmodernom ambijentu", Banja Luka, 26-27.07.2009, Banja Luka: Panevropski univerzitet APEIRON, retrieved on 10.01. 2018 from: http://apeironsrbija.edu.rs/icama2009/039_Suzana\%20Pajic\%20-\%20Uticaj\%20klimatskih\%20promjena\%20na\%20zivotnu\%20sre.pdf.

Climate Action: 2030 climate and energy framework, retrieved on 12.01. 2018 from: https://ec.europa.eu/clima/policies/strategies/2030_en

Communication from the Commission to the European Parliament, the Council, the European Economic and Social Committee and the Committee of the Regions a policy framework for climate and energy in the period from 2020 to 2030, Brussels, 22.1.2014 COM(2014) 15 final, \{SWD(2014) 15 final $\}$ SSWD(2014) 16 final\}, http://eur-lex.europa.eu/legal-content/EN/TXT/PDF/?uri=CELEX:5201 4DC0015\&from=EN, 12.01.2018. 
The Paris Agreement, United Nations, 2015, http://unfccc.int/files/essential_background/convention/application/pdf/english_paris_agreement.pdf, 11.01.2018.

Popović, T., Radulović, E., Jovanović, M. (2005): Koliko nam se menja klima, kakva će biti naša buduća klima. Životna sredina ka Evropi. Beograd: Agencija za zaštitu životne sredine, http://www.sepa.gov.rs/download/5_web.pdf, 10.01.2018.

Pregovarački tim za vođenje pregovora o pristupanju Republike Srbije Evropskoj uniji, Poglavlje 27: Životna sredina, http://www.eu-pregovori.rs/srl/pregovaracka-poglavlja/poglavlje-27-zivotna-sredina/, 10.01.2018.

Commission Staff Working Document, Serbia 2016 Report, accompanying the document Communication from the Commission to the European Parliament, the Council, the European Economic and Social Committee and the Committee of the Regions 2016, Communication on EU Enlargement Policy \{COM(2016) 715 final\}, Brussels, 9.11.2016., SWD(2016) 361 final, https://ec.europa.eu/neighbourhoodenlargement/sites/near/files/pdf/key_documents/2016/20161109_report_serbia.pdf, 26.03.2018.

Reference: C.N.735.2016.TREATIES-XXVII.7.d (Depositary Notification), Paris Agreement, Paris, 12 December 2015, Entry into Force, https://treaties.un.org/ doc/Publication/CN/2016/CN.735.2016-Eng.pdf, 11.01.2018.

Abbreviated Fifth Report of the International Panel for Climate Change, http:// www.hidmet.gov.rs/podaci/ipcc/Skraceni_peti_izvestaj_IPCC.pdf, 10.01.2018.

Status of Ratification of the United Nations Framework Convention on Climate Change, United Nations Climate Change, http://unfccc.int/essential_background/convention/status_of_ratification/items/2631.php, 11.01.2018.

United Nations Framework Convention on Climate Change, United Nations, 1992, http://unfccc.int/files/essential_background/background_publications_ htmlpdf/application/pdf/conveng.pdf, 10.01.2018.

Act on Ratification of the Kyoto Protocol to the United Nations Framework Convention on Climate Change, Official Gazette of the Republic of Serbia-International Agreements, No. br. 88/2007 and 38/2009.

United Nations Framework Convention on Climate Change, United Nations, 1992, http://unfccc.int/files/essential_background/background_publications_ htmlpdf/application/pdf/conveng.pdf, 10.01.2018.

Act on the Ratification of United Nations Framework Convention on Climate Change, with Annexes, Official Gazette of the Republic of Serbia-International Agreements, No.2/1997. 
Todić, D. (2014) Klimatske promene u pravu i reforma sistema upravljanja. Beograd: Institut za međunarodnu politiku i privredu

Todić, D. (2016) Pariski sporazum o klimi u svetlu ciljeva i principa savremene politike i prava životne sredine. Megatrend revija, 13(3), str. 45-62.

Decision No 1386/2013/EU of the European Parliament and of the Council of 20 November 2013 on a General Union Environment Action Programme to 2020 "Living well, within the limits of our planet", Official Journal of the European Union L 354/171, 28.12.2013., http://eur-lex.europa.eu/legal-content/EN/TXT/ PDF/?uri=CELEX:32013D1386\&from=EN, 11.01.2018.

Environment Action Programme to 2020, http://ec.europa.eu/environment/ action-programme/, 11.01.2018.

Communication from the Commission to the Council and the European Parliament, Thematic Strategy on air pollution $\{$ SEC(2005) 1132\}\{SEC(2005) 1133\}, Brussels, 21.9.2005. COM(2005) 446 final, http://eur-lex.europa.eu/legal-content/EN/TXT/PDF/?uri=CELEX:52005DC0446\&from=EN, 11.01.2017.

Communication from the Commission to the Council, the European Parliament, the European Economic and Social Committee and the Committee of the Regions - Thematic Strategy for Soil Protection [SEC(2006)620] [SEC(2006)1165], Brussels, Brussels, 22.9.2006. COM(2006)231 final, http://eur-lex.europa.eu/ legal-content/EN/TXT/PDF/?uri=CELEX:52006DC0231\&from=EN, 11.01.2017.

Communication from the Commission to the Council, the European Parliament, the European Economic and Social Committee and The Committee of the Regions - Taking sustainable use of resources forward - A Thematic Strategy on the prevention and recycling of waste $\{\mathrm{SEC}(2005) 1681\}\{\mathrm{SEC}(2005) 1682\}$, Brussels, 21.12.2005. COM(2005) 666 final, http://eur-lex.europa.eu/legal-content/EN/ TXT/PDF/?uri=CELEX:52005DC0666\&from=EN, 11.01.2017.

Communication from the Commission, Europe 2020 A strategy for smart, sustainable and inclusive growth, Brussels, 3.3.2010.COM(2010) 2020, http:// ec.europa.eu/eu2020/pdf/COMPLET\%20EN\%20BARROSO\%20\%20\%20 007\%20-\%20Europe\%202020\%20-\%20EN\%20version.pdf, 12.01.2018.

Climate Action, 2020 climate and energy package, https://ec.europa.eu/clima/ policies/strategies/2020_en, 12.01.2018.

The EU Emissions Trading System (EU ETS) Factsheet, https://ec.europa.eu/ clima/sites/clima/files/factsheet_ets_en.pdf, 12.01.2018.

Srbija i klimatske promene, EU sistem trgovine emisijama, http://www.klimatskepromene.rs/obaveze-prema-eu/eu-sistem-trgovine-emisijama/, 12.01.2018. 
Directive 2003/87/EC of the European Parliament and of the Council of 13 October 2003 establishing a scheme for greenhouse gas emission allowance trading within the Community and amending Council Directive 96/61/EC, Official Journal of the European Union, L 275/32, 25.10.2003, http://eur-lex.europa.eu/ legal-content/EN/TXT/PDF/?uri=CELEX:32003L0087\&from=EN, 12.01.2018.

Directive 2004/101/EC of the European Parliament and of the Council amending Directive 2003/87/EC establishing a scheme for greenhouse gas emission allowance trading within the Community, in respect of the Kyoto Protocol's project mechanisms, Official Journal of the European Union, L 338/18, 13.11.2004, http://eur-lex.europa.eu/legal-content/EN/TXT/PDF/?uri=CELEX:32004L010 $1 \&$ from $=\mathrm{EN}, 12.01 .2018$.

Directive 2008/101/EC of the European Parliament and of the Council amending Directive 2003/87/EC so as to include aviation activities in the scheme for greenhouse gas emission allowance trading within the Community, Official Journal of the European Union, L 8/3,13.1.2009, http://eur-lex.europa.eu/legal-content/ EN/TXT/PDF/?uri=CELEX:32008L0101\&from=EN, 12.01.2018.

Directive 2009/29/EC of the European Parliament and of the Council of 23 April 2009 amending Directive 2003/87/EC so as to improve and extend the greenhouse gas emission allowance trading scheme of the Community, Official Journal of the European Union, L 140/63, 5.6.2009, http://eur-lex.europa.eu/ legal-content/EN/TXT/PDF/?uri=CELEX:32009L0029\&from=EN, 12.01.2018.

Directive 2003/87/EC of the European Parliament and of the Council of 13 October 2003 establishing a scheme for greenhouse gas emission allowance trading within the Community and amending Council Directive 96/61/EC, Official Journal of the European Union, 275, 25.10.2003, http://eur-lex.europa.eu/legal-content/EN/TXT/PDF/?uri=CELEX:02003L0087-20140430\&from=EN, 12.01.2018.

Climate Action, The EU Emissions Trading System, https://ec.europa.eu/clima/ policies/ets_en\#Main_legislation, 12.01.2018.

Directive 2001/81/EC of the European Parliament and of the Council of 23 October 2001 on national emission ceilings for certain atmospheric pollutants, Official Journal of the European Communities, L 309/22, 27.11.2001, http:// eur-lex.europa.eu/legal-content/EN/TXT/PDF/?uri=CELEX:32001L0081\&fro $\mathrm{m}=\mathrm{EN}, 12.01 .2018$.

Directive 2010/75/EU of the European Parliament and of the Council of 24 November 2010 on industrial emissions (integrated pollution prevention and control), Official Journal of the European Union, L 334/17, 17.12.2010., http:// eur-lex.europa.eu/legal-content/EN/TXT/PDF/?uri=CELEX:32010L0075\&fro $\mathrm{m}=\mathrm{EN}, 12.01 .2018$. 
Directive 2009/28/EC of the European Parliament and of the Council of 23 April 2009 on the promotion of the use of energy from renewable sources and amending and subsequently repealing Directives 2001/77/EC and 2003/30/ EC, Official Journal of the European Union, L 140/16, 5.6.2009., http://eur-lex. europa.eu/legal-content/EN/TXT/PDF/?uri=CELEX:32009L0028\&from=EN, 12.01.2018.

The Doha Amendment to the Kyoto Protocol, http://unfccc.int/files/kyoto_protocol/application/pdf/kp_doha_amendment_english.pdf, 26.03.2018.

Act on Ratification of Paris Agreement, Official Gazette of the Republic of SerbiaInternational Agreements, No. 4/2017. 


\title{
Др Ана Батрићевић,
}

Виши научни сарадник,

Институт за криминолошка и социолошка истраживања, Београд, Република Србија

\section{ПРАВО ЕВРОПСКЕ УНИЈЕ И ИЗАЗОВИ КЛИМАТСКИХ ПРОМЕНА}

\begin{abstract}
Резиме
Последњих неколико деценија, Европска унија чини значајне напоре на плану борбе против климатских промена. Као међународна организација, Европска унија је до сада ратификовала низ кључних међународних докумената који се баве проблематиком климатских промена укључујући: Оквирну конвенцију Уједињених нација о промени климе, Кјото протокол и Париски споразум. Поред тога, Европска унија је изградила богат правни оквир од значаја за превенцију климатских промена и сузбијање њихових негативних последища, који укључује бројне одлуке, директиве, тематске стратегије и акционе програме. Главни циљ свих ових правних аката јесте смањење и контролисање емисија гасова са ефектом стаклене баште, како би се допринело смањењу загађења, повећању енергетске ефикасности и ублажавању негативних последица климатских промена. Извештаји о примени наведених извора права Европске уније у њеним државама чланицама потврђују да је примена мера предвиђених различитим изворима ацqуис-а из ове области у тим земљама дала позитивне резултате. Међутим, релевантни извештаји такође показују да климатске промене и даље представљајуозбиљан изазов како за законодавце тако и за све друге субјекте који својим делатностима могу допринети овом феномену. Имајући у виду да Републици Србији предстоји отварање преговарачког поглавља 27, које је управо посвећено животној средини и климатским променама, аутору овом раду анализира:релевантне међународне документе универзалног поља примене чијаје чланища и Европска унија, изворе ацqуис-а од значаја за суочавање са климатским променама, као и извештаје о постигнутим резултатима у борби против климатских промена како на нивоу Европске уније, тако и у њеним државама чланицама. Такође, аутор разматра и међународне обавезе Републике Србије у овој области, њен досадашњи напредак на овом плану и кораке које ће наша земља морати у да предузме будућности како би те обавезе испунила, нарочито у контексту предстојећег отварања преговарачког поглавља 27, посвећеног животној средини и климатским променама.
\end{abstract}

Кључе речи: Европска унија, климатске промене, животна средина, екологија, еколошко право. 
